\title{
Water and Food Nexus: Role of Socio-Economic Status on Water-Food Nexus in an Urban Agglomeration Hyderabad, India Using Consumption Water Footprint
}

\author{
Koteswara Rao. D. *, Satish K. Regonda and Chandrasekharam Dornadula
}

check for updates

Citation: D., K.R.; Regonda, S.K.; Dornadula, C. Water and Food Nexus: Role of Socio-Economic Status on Water-Food Nexus in an Urban Agglomeration Hyderabad, India Using Consumption Water Footprint. Water 2021, 13, 637. https://doi.org/ $10.3390 / w 13050637$

Academic Editors: Maite M. Aldaya, Diego Sesma-Martín and Joep F. Schyns

Received: 24 December 2020 Accepted: 23 February 2021 Published: 27 February 2021

Publisher's Note: MDPI stays neutral with regard to jurisdictional claims in published maps and institutional affiliations.

Copyright: (c) 2021 by the authors. Licensee MDPI, Basel, Switzerland. This article is an open access article distributed under the terms and conditions of the Creative Commons Attribution (CC BY) license (https:// creativecommons.org/licenses/by/ $4.0 /)$.
Department of Civil Engineering, Water Resources Division, Indian Institute of Technology Hyderabad, Sangareddy, Kandi Village, Telangana 502285, India; satishr@ce.iith.ac.in (S.K.R.); dchandra@ce.iith.ac.in (C.D.) * Correspondence: koteswararaodagani@gmail.com; Tel.: +91-9966709029

\begin{abstract}
Cities are complex and evolving systems with various factors playing key roles, e.g., population increase, the migration of population, the availability of resources, and the flexibility of policies. Consumers' socioeconomic status is also an important aspect that needs to be studied in the context of a self-reliant urban city in its resource consumption. In this regard, the association between water-food and socio-economic attributes was analyzed based on the consumer-centric approach for the Hyderabad Metro Development Authority (HMDA) region, India. In this study, the embedded water content in food consumption was estimated and analyzed for nine food groups and twelve economic classes of the HMDA region. The middle economic classes were found to correspond to $\sim 80 \%$ of embedded water content in the HMDA region, followed by the upper and lower economic classes. Except for cereals, per capita, the water consumption of all food groups increased with the spending power of the economic class. The green, blue, and grey consumption water footprints (WFs) suggested that much of the water that is being consumed in the HMDA region is precipitation-driven, followed by surface and groundwater resources. Limited water resources, water resource variability, climate change consequences including future climate projections, uncertainty in data, WF estimates, and region's future growth imply a detailed study in drafting policies to become a self-reliant region.
\end{abstract}

Keywords: embedded water content; water footprint; water-food nexus; socio-economic status; food consumption; virtual water; spending capacity

\section{Introduction}

Drafting globalized policies for the sustainable consumption of resources in urban regions is necessary. The increase in the role of urban regions by hosting significant population as well as providing various opportunities is reflected in its contribution to the national economy and, thereby, the global economy. As per the European Commission, urban regions (or urban cities) hosted $75 \%$ of the global population in 2015 , and the population has risen relatively quickly in recent times [1]. Additionally, significant changes in land use and land cover have been observed. Importantly, agricultural land in periurban regions, which plays a crucial role in cities' food supplies [2,3], has shrunk [4]. Increases in population and decreases in resourceful land in combination with cities' growing requirements further add more stress to available resources including water, which is limited in quantity and variable with time.

Water is the key resource used by all elements of an urban region, and food is an entity that consumes a significant amount of water [5]. Food imports imply the importation of water from both near and faraway places; however, only a few studies have explored water movement across different sectors, particularly in the context of food consumption and its impacts on regional water balance at the city scale [6-8]. This has led to a poor understanding of water and food association at the urban and regional scales. Note that the unavailability of data and gaps in data are also limiting factors for the perusal of 
systematic efforts [6,8]. Nevertheless, both rapid economic growth and lifestyle changes have introduced new food habits that consist of more processed foods that are waterintensive in production [9-11]. These situations lead cities to be hotspots for the higher consumption of direct and indirect water resource utilization, increasing further water stress in a region $[12,13]$. Direct and indirect water resource computation and its movement across different regions and sectors is complex and requires systematic study. The nexus approach offers a practical solution, including for transboundary conflicts [5].

The nexus approach got its first attention in the world economic forum conference in 2011 [14]. The approach measures the interdependencies between water-energy-food (WEF) resources by accounting for the water used in various tasks, including production, transportation, and regional consumption. Thus, the information from the nexus approach can be used for governance and planning, as well as to evaluate trade-offs between WEF resources [5,15]. The nexus approach can be applied to the city, river basin, and continental scales from different perspectives of the water footprint $[5,8,16,17]$. The water-energyfood nexus approach suggests localized solutions specific to a region. Note that nexus studies have been pursued from different perspectives like food [18,19], energy [20,21], and climate [22-24] for regions of different areas. Additionally, an integrated tool to assess the WEF nexus was also developed [25]. Urban regions are hotspots for consumption; indeed, they consume more virtual water that is approximately 20 times more than direct water consumption [26], and it highlights the need to quantify the water and food nexus at the city scale. However, the application of the nexus approach to the city scale is relatively more complex compared to regions of a large spatial scale, e.g., river basins or continents. This is mainly due to the transboundary nature of resource consumption in urban cities $[6,27,28]$, and only a few studies have addressed the water-food nexus at the city scale.

The food consumption of urban cities involves long supply chains with production, processing, and mobilization stages, and water is the central element in every stage [29,30]. These long supply chains increase water, energy, and food footprints in the pre-consumption of food, the post-consumption of food, and greenhouse gas (GHG) emissions [29,30]. Among the consequences of various socio-economic-environment elements, increased pressure on water resources is the most notable. Despite being the primary element in determining the water footprint, human consumption of water and food remains sparsely examined in the context of the urban food systems in various cities [29,31-38].

Many studies have analyzed the nexus between water-centered resources in highincome economic regions that are data-rich and use regional trade [18,19,39,40]. A few studies have considered commodity survey data [29,30], which is a coarse representation of the nexus of urban food systems, and consumers' socio-economic status has not been considered. Consumers' socioeconomic status is an important representational aspect in an urban system, and its role has further increased as urban regions have grown and differences in economic classes have widened [41]. Only a few studies have pursued the nexus by integrating consumers' socio-economic information for cities in Europe [37,42]. The fact that the changes vary significantly among urban dwellers of different economic classes emphasizes the need to have detailed data; however, data unavailability is common for many urban regions across the world. In this regard, the consumer-centric approach [43-46] is a reasonable solution to overcome the data-related issues for nexus studies.

In recent times, particularly during Coronavirus disease-2019 (COVID-19)-driven lockdowns, self-reliance on food and water resources has become a primary concern for many urban regions. The biggest importers have faced challenges because of COVID-19driven lockdown restrictions on exports, and uncertainties in removing or easing lockdown restrictions increased difficulties further [47-49]. Covarrubias and Boas [6] analyzed the accessibility of proximity of food in the context of reducing food miles, energy utilization, and carbon emissions to understand how the city of Barcelona could be self-reliant for food consumption. Similarly, climate change consequences have the potential to bring the notion of self-reliance to cities. Climate change effects include a range of consequences, and in the context of food systems, changes in rainfall and temperature have important roles. 
Changes in rainfall patterns on both small and large space and time scales have resulted in hydroclimate extremes such as floods and droughts at the city and river basin scales [50]. Additionally, temperature changes might produce other extremes such as heatwaves [51]. As it has been seen, these effects disrupt food system elements, and cities are relatively more vulnerable because these elements are highly dependent on peri-urban and regions elsewhere.

Most of the food products consumed in India are produced within the domestic boundaries; therefore, the impact of India's imported food trade is less significant on any part of the world in terms of the water footprint [29,52,53]. However, India is a source for water-intensive food trade, exporting 95.4 billion cubic meters/year of virtual water in the food trade, which is four times what India is consuming [54,55]. A high consumption of unevenly distributed water resources for exports is a primary reason for water stress conditions in the major cities of India [54]. In this context, India, including its urban regions, needs to cautiously monitor and secure its water-centered resources. In particular, India's smart cities mission further emphasizes this need, as more cities are planned to be developed shortly [56].

Ramaswami et al. [28] analyzed and quantified the impact of climate on the water, energy, and food nexus of Delhi city, India, for urban food systems [28]. This study revealed the transboundary interactions and interdependency of resources for the provision of water, energy, and food needs. Boyer addressed sustainability and environmental impacts by analyzing the unique food systems of nine Indian cities $[29,30]$. The authors also compared the food system characteristics of cities from India and United States, and they found differences in the food supply chain distance in the cities of both counties. They found relatively long food supply chain distances in Indian cities, this along with the increased consumption of water and energy, and the GHG emissions impacted the environment. The study also observed a large amount of pre-consumer food waste, though this was slightly higher in cities of the USA than in Indian cities. Typically, planning trade strategies and drafting water policies at the regional and national levels only consider available water resources, and the accountability of socio-material flow (embedded water in the supply chain) between transboundary regions is not given much importance [6-8]. This may be due to the lack of a common platform to deal with the nexus between water-centered resources. Regional food resiliency is frequently disturbed with floods and droughts, and it builds a competitive trade-off in allocating water resources between food production and domestic needs, thus leading to various transboundary conflicts [5,57].

While India's smart city mission facilitates the development of a systematic urban database in the near future, the evolution of cities into further complex systems poses challenges and difficulties in finding optimal solutions. The notion of becoming a selfreliant city drives sustainable city policies for various reasons including climate change, and it is important to understand the water footprint from various angles, including socioeconomic status for the aforementioned reasons. In this regard, the main objective of the study was to understand the association between socio-economic attributes, including purchasing power, food consumption, and embedded waters in the Hyderabad Metro Development Authority (HMDA) region. Thus, the study can assist policymakers of local and national governments in providing information on water-intensive and waterfriendly food products, as well as in developing trade strategies with water-rich regions so that the consumption of water in urban and peri-urban regions will eventually decrease. The information may play a role in drafting city-level food policies for the sustainable consumption of food and water resources to build sustainable and smart cities, which is part of the second, sixth, and eleventh goals of the United Nations' Sustainable Development Goals that were established in 2015 [58]. The trade strategies emphasize the revisiting of the water allocation trade-offs between food production and other domestic purposes, so regional water balance accounting export and import of virtual water is achieved. 


\section{Study Area}

The study region, HMDA, includes Hyderabad, which is one of the most well-known cosmopolitan cities in India. Hyderabad city is capital of the relatively newly formed state Telangana, and the selected region, HMDA, has a wide variety of food cultures because people in the region are from different parts of the country. Approximately $70 \%$ of the HMDA's water footprint (WF) is due to food consumption [46], and the region's produce depends on food products from surrounding regions, particularly it's peri-urban region; the key role of the peri-urban region in agriculture products is evident in HMDA's food supply [2]. The agriculture and domestic water needs of these peri-urban regions are compromised to satisfy the water needs of the HMDA region, thus leading the peri-urban regions to have water conflict [59].

Initially, Hyderabad only up reached the boundaries of erstwhile Hyderabad (see Hyderabad part in Figure 1) with an area of $217 \mathrm{~km}^{2}$, and rapid economic activity mainly led by information technology services resulted in exponential population growth and changes in land use. Consequently, the city expanded to $7257 \mathrm{~km}^{2}$ and parts of surrounding districts-Ranga Reddy, Medak, Nalgonda, and Mahabubnagar-became the city's periurban regions [60]. The total population of the HMDA region is 9.4 million, and Hyderabad is the fourth most populous urban agglomeration in India [61]. Hyderabad is located on one of the riverbanks of River Musi, which is the tributary of River Krishna; however, another part of the study region is in another major river catchment, the Godavari river basin. The region gets most of its rainfall during the monsoon season, and the average annual rainfall of the Hyderabad region is $810 \mathrm{~mm}$. The city consumes 1030 and 257 million liters per day for domestic and industrial purposes, respectively, and most of its water come from reservoirs, which range from within city limits to as far as $300 \mathrm{~km}$ away from the city (from annual reports of Hyderabad Metro Water Supply and Sewerage Board, 2016). Both the growing city's requirements and industry-driven, pollution-related issues on the city's water resources have compelled the region to depend on water resources far from the city limits [62]. 


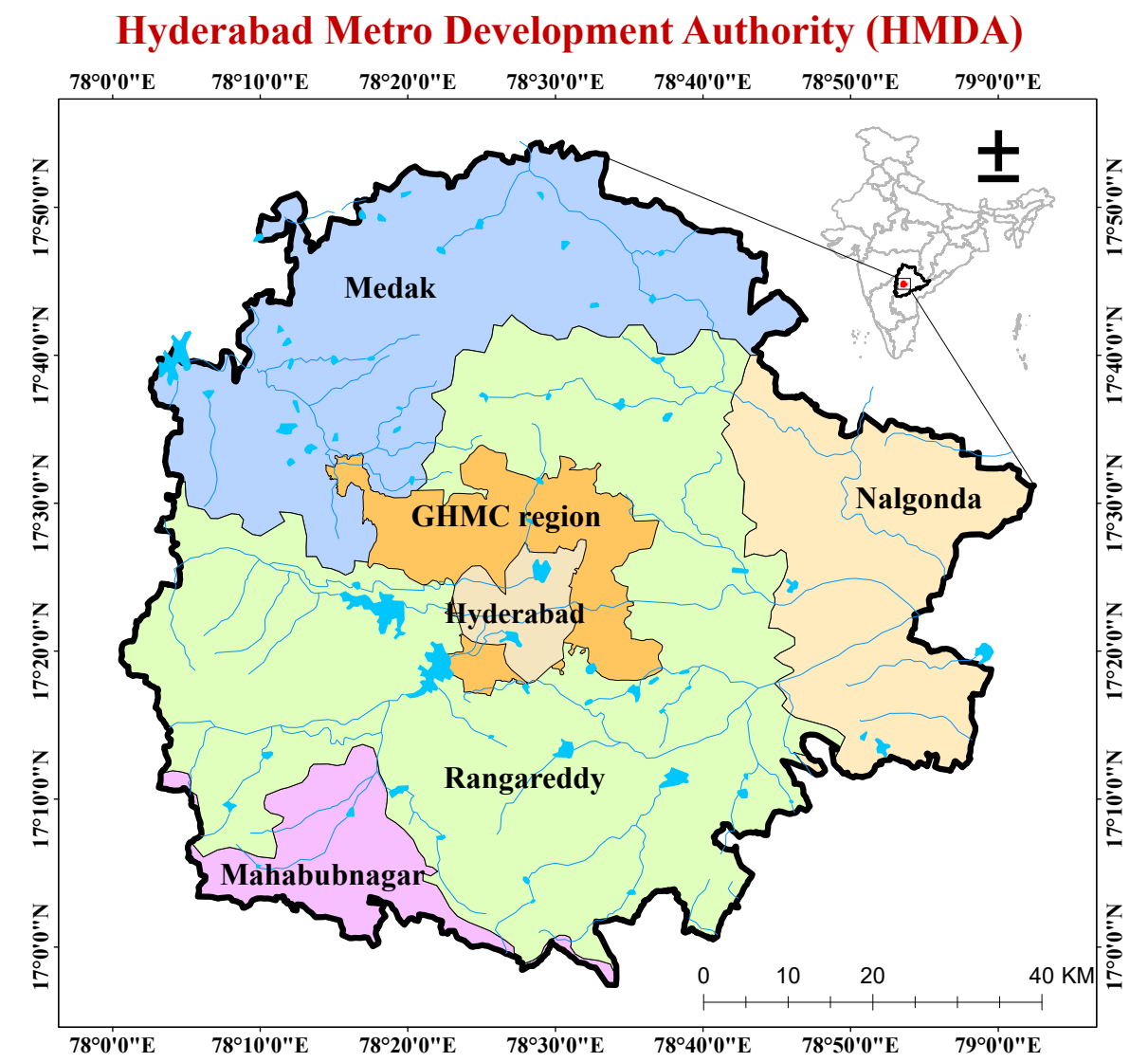

Figure 1. Jurisdictions of Hyderabad Metropolitan Development Authority (HMDA) region showing the boundaries of Greater Hyderabad Municipal Corporation (GHMC) and five districts, i.e., Hyderabad, Ranga Reddy, Nalgonda, Medak and Mahabubnagar.

\section{Materials and Methods}

\subsection{Data}

The data that were considered in this study are as follows: consumed food quantities, population, and water production footprint. Additionally, the commodity consumption data from the 68th consumer expenditure survey were used. The survey was conducted in 2012 by the National Sample Survey Organization (NSSO) [63], and the data consisted of consumed quantities for 88 food products for each of twelve economic classes for the HMDA region. The economic classes (ECs) were formed based on the monthly per capita consumption expenditure (MPCE) [63]. The food products were grouped into 9 food groups, namely cereals, fruits, livestock, coffee and tea, milk products, oils and fats, pulses, sugars, and vegetables, as per dietary guidelines of National Institute of Nutrition India [64]. Population data for each economic class for the HMDA region were obtained from the comprehensive transport survey of the HMDA [60]. The water production footprint, including green, blue, and grey water footprints for all individual food products, was taken from a well-known database $[65,66]$.

\subsection{Method}

The study used a consumer-centric approach to quantify the water and food nexus for the study region in the context of socioeconomic status, and it adopted the framework developed by [46]. As shown in Figure 2, the study calculated the total amount of consumed food, and then it calculated the embedded water for each food commodity for and economic class. The embedded waters were used to analyze the water and food nexus for food groups, economic classes, and the HMDA region. Figure 3 shows the finer details of data and the 
calculation procedure. The below-mentioned steps detail the calculations and assist in the interpretation of results.

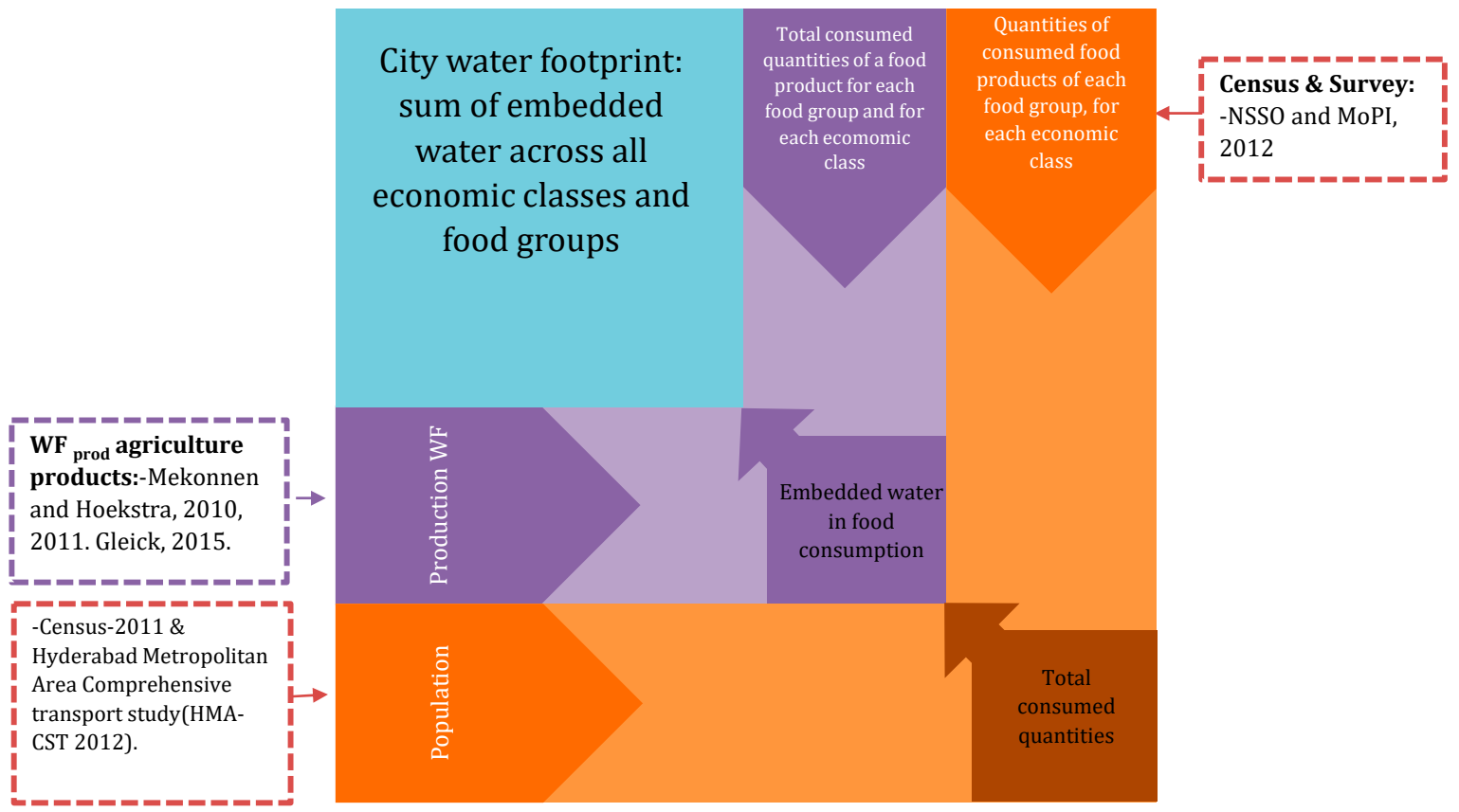

Figure 2. The framework to account for water footprint and the data used to assess the water, food, and economic nexus of Hyderabad. The arrows indicate the direction of their multiplier to quantify the central elements: total food consumption quantities of a food product for each economic class, the embedded water content in food consumption for each food product and each economic class, and city-level embedded water contents in food consumption. WF: water footprint; NSSO: National Sample Survey Organization.

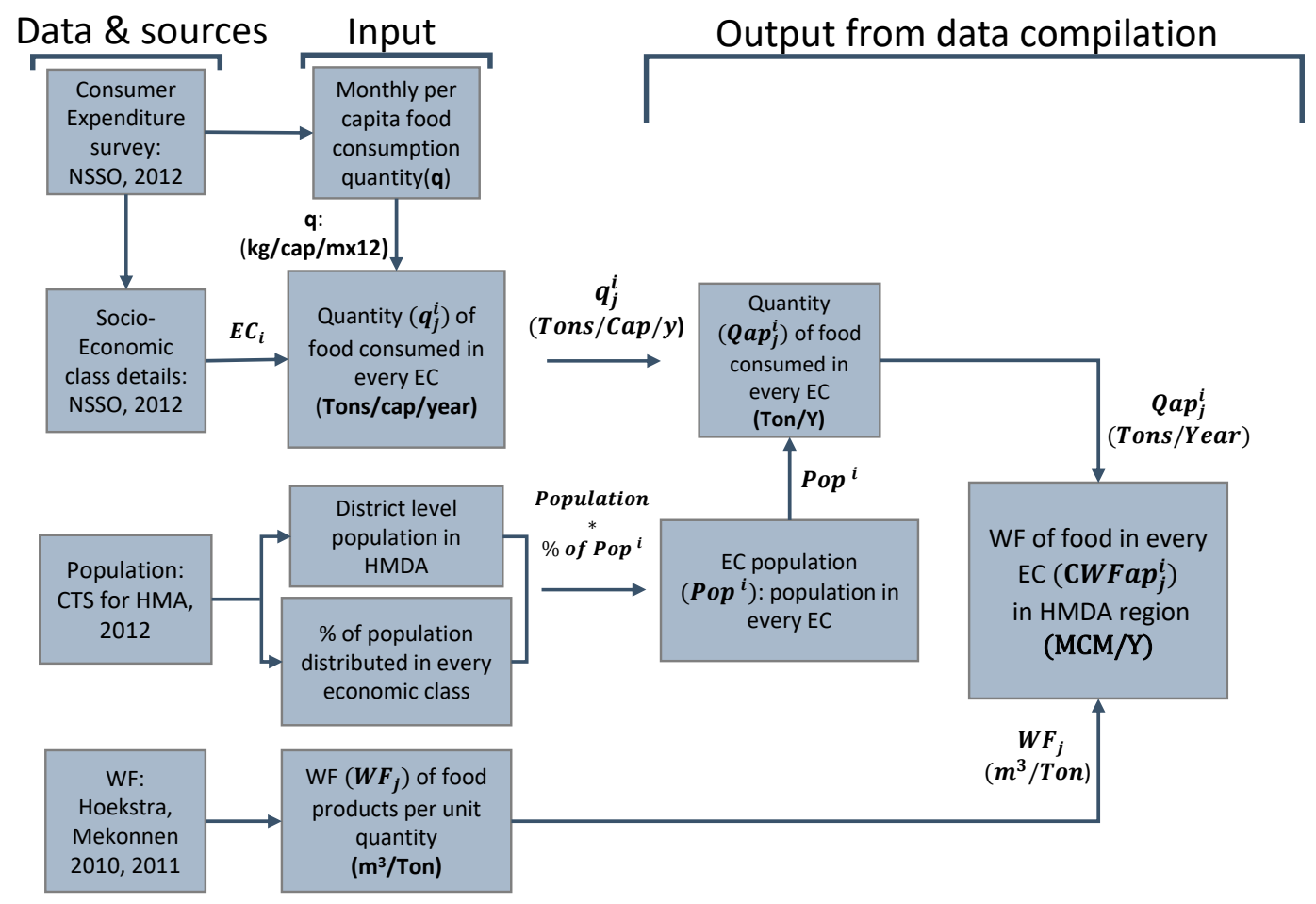

Figure 3. Calculation procedure to quantify embedded water content in food consumption for each food product and each economic class, and city-level embedded water contents in food consumption. EC: economic class. 
Stepwise calculation procedure:

Step 1: Calculate food consumption quantities in tons per capita per year $\left(q_{j}^{i}\right)$ for all food products ( $\mathrm{j}$ ) and each economic class (i) using monthly per capita consumption quantities (q).

Step 2: Calculate the population for each economic class $\left(\right.$ Pop $\left.^{i}\right)$ using the percentage of the population in each EC and the total population in the HMDA region.

Step 3: Calculate the total consumed quantities $\left(Q_{\text {total }}^{i}{ }_{j}^{j}\right.$ for all food products (j) and each economic class (i) using information from steps (1) and (2).

$$
\operatorname{Qtotal}_{j}^{\mathrm{i}}(\text { Tons } / \text { year })=\mathrm{q}_{j}^{\mathrm{i}}(\text { Tons } / \text { cap } / \text { year }) \times \text { Pop }^{\mathrm{i}}
$$

Step 4: Calculate embedded waters, i.e., consumption $W F\left(C W F_{j}^{i}\right)$, for each economic class and each food product using the corresponding water production footprint $\left(\mathrm{WF}_{\mathrm{j}}\right)$ and total consumed quantity $\left(\right.$ Qtotal $\left._{j}^{i}\right)$.

$$
\mathrm{CWF}_{\mathrm{j}}^{\mathrm{i}}(\mathrm{MCM} / \mathrm{y})=\operatorname{Qtotal}_{\mathrm{j}}^{\mathrm{i}}(\text { Tons } / \mathrm{y}) \times \mathrm{WF}_{\mathrm{j}}\left(\mathrm{m}^{3} / \text { Tons }\right)
$$

This step is repeated for all three green, blue, and grey production WFs, and the sum of the three individual embedded waters yields the total embedded waters.

Step 5: Calculate the embedded waters for each economic class (i) and for each of the nine food groups (J) by summing embedded waters of corresponding food products.

$$
\mathrm{CWF}_{\mathrm{j}}^{\mathrm{i}}(\mathrm{MCM} / \text { year })=\sum_{\mathrm{j}=1}^{\mathrm{jj}} \mathrm{CWF}_{\mathrm{i}}(\mathrm{MCM} / \text { year })
$$

where $J j$ is the number of food products in the food group J.

The embedded water of the HMDA region was calculated as shown below.

$$
\mathrm{CWF}_{\mathrm{HMDA}}(\mathrm{MCM} / \text { year })=\sum_{\mathrm{i}=1}^{12} \sum_{\mathrm{J}}^{9} \mathrm{CWF}_{\mathrm{J}}^{\mathrm{i}}(\mathrm{MCM} / \text { year })
$$

In addition, the per capital consumption quantity, total consumed food quantities' percentage equivalent concerning food groups, total embedded water's percentage equivalent concerning food groups, and production WF (which corresponds to consumed water during production of a food product) for each food group were calculated. The production WF was calculated as the sum of production WF of all food products of a food group. The percentage equivalent calculations reflected the contribution from every food group.

Food groups were categorized as water-intensive, water-neutral, or water-friendly based on the difference between the percentage equivalent of embedded waters and the percentage equivalent of food consumption. If the value of the difference, i.e., percentage point difference, was positive and greater than 2 , then the corresponding food group was treated as water-intensive. If the value of the difference was negative and smaller than -2 , then the food group was treated as water-friendly. If the values were between -2 and +2 , then the food groups were treated as water-neutral. The threshold of ' 2 ' was used to account for the errors in the uncertainties, and it was subjective.

\section{Results and Discussion}

\subsection{Water and Food Nexus in HMDA Region}

Table 1 lists the total consumed food quantities and embedded water, i.e., water consumption footprint and production WF, for each of the nine food groups and for the HMDA region, which includes all 12 economic classes. The table also has percentage equivalents for total consumed food quantity (column 3) and embedded waters (column 5), as well as the percentage point difference of these two quantities (column 8). The total 
embedded water in food consumption was found to be $6833 \mathrm{MCM} / \mathrm{year}$, and it was more than 20 times the HMDA region's direct water use, i.e., $375 \mathrm{MCM} /$ year [46]. Among all the food groups, cereals, milk products, and livestock together contributed $73 \%$ (i.e., $4995 \mathrm{MCM}$ /year) of the total embedded water, and the remaining six food groups, i.e., pulses, vegetables, fruits, oils and fats, sugars, and coffee and tea corresponded to $27 \%$ (column 5, Table 1). However, in terms of the total consumed food quantity, cereals, vegetables, and milk products contributed $79 \%$ of food consumed in the HMDA region. While cereals and milk products were found to be the highest contributing food groups in terms of both embedded water and consumed food quantity, livestock and vegetables also significantly contributed to embedded water and consumed food quantity, respectively. We defined a water-intensive food group as a group with a positive difference between the percentage equivalent of embedded water content and the percentage equivalent of food consumption categorizes cereals; as such, pulses and livestock were found to be water-intensive food groups. Cereals were the most water-intensive of the food groups, with a difference of $11 \%$ between the percent of embedded water and food consumption. Therefore, this can be treated as the most water-intensive food group, whereas livestock and pulses differed by 6 and 4\%, respectively, in their proportion of embedded water content and their respective food consumption quantities. Therefore, these products can be treated as less water-intensive food groups. Due to their small values and uncertainty in the data, the fats and oils, coffee and tea, sugars, and milk product groups can be treated as water-neutral food groups. Unlike the above-mentioned products, vegetables and fruits were found to have lesser proportions of percent equivalents of embedded water content than their respective percent equivalent of food consumption, i.e., 18 and $4 \%$, respectively. This implies that there is a relatively smaller percentage of consumed water than that of consumed food quantities at the city level, hence vegetables and fruits can be treated as water-friendly food groups.

It is interesting to note that cereals, vegetables, and milk products were found to be the most highly consumed food products in the HMDA region at 1.04, 0.75, and 0.69 tons/year, respectively. However, the corresponding total embedded waters by each of these food groups at the city level differed by significant amounts. Therefore, these food groups were labelled as water intensive, water-friendly, and water-neutral, respectively. The water production footprint of cereals (i.e., the embedded water content in production) was of medium value compared to the other products (see Table 1). However, its relatively high consumed quantities, i.e., 33\% of the total food consumed across the HMDA, made the food group more water-intensive. Meanwhile, vegetables and milk products consumed approximately the same amount, i.e., 0.75 and 0.69 tons/year, respectively, but their production WF was greatly different at 2011 and 543 liters $/ \mathrm{kg}$, respectively. Hence they were treated as water-friendly and water-neutral food groups, respectively, for the HMDA region. Livestock and pulses consumed small quantities, i.e., $~ 0.1$ tons/year ( $3 \%$ of total quantity), but their high production WF made them moderate water-intensive food groups. The sugars group and the oils and fats group consumed similar quantities, i.e., $~ 0.1$ tons/year, but their relatively low production WF made them water-neutral. The group of coffee and tea had the highest production WF, but its relatively very small consumption quantity of $\sim 0.01$ tons/year corresponded to relatively similar low embedded waters at the city level. Consequently, this food group was treated as water-neutral food. As discussed, the food groups differed in their quantity, production WF, and, consequently, their embedded water quantities at the city level. However, after learning that these consumed quantities varied in each economic class, it was important to analyze them more for a better understanding of the water-food nexus at the sub-city level. 


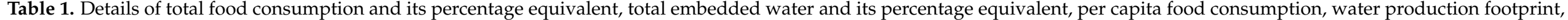
and category of food groups for the HMDA region (MCM: million cubic meters).

\begin{tabular}{|c|c|c|c|c|c|c|c|c|}
\hline Food Group & $\begin{array}{c}\text { Total Food } \\
\text { Consumption } \\
\text { (million tons/year) }\end{array}$ & $\begin{array}{c}\text { Percentage } \\
\text { Equivalent of Total } \\
\text { Food Consumption }\end{array}$ & $\begin{array}{l}\text { Total Embedded Water } \\
\text { (MCM/year) }\end{array}$ & $\begin{array}{c}\text { Percent Equivalent } \\
\text { of Total Embedded } \\
\text { Water }\end{array}$ & $\begin{array}{l}\text { Per Capita } \\
\text { Consumption } \\
\text { (Kg/year) }\end{array}$ & $\begin{array}{l}\text { Production WF } \\
\text { (Liters/Kg) }\end{array}$ & $\begin{array}{l}\text { Difference between Percent } \\
\text { Equivalent of Total Embedded } \\
\text { Water and Percent Equivalent of } \\
\text { Total Food Consumption }\end{array}$ & Category \\
\hline Cereals & 1.04 & 33 & 2973 & 44 & 111.21 & 2839 & 11 & Water-intensive \\
\hline Pulses & 0.1 & 3 & 453 & 7 & 11.2 & 4300 & 4 & Water-intensive \\
\hline Sugars & 0.1 & 3 & 229 & 3 & 10.56 & 2255 & 0 & Water-neutral \\
\hline Milk products & 0.69 & 22 & 1387 & 20 & 73.29 & 2011 & -2 & Water-neutral \\
\hline Fats and oils & 0.1 & 3 & 341 & 5 & 10.67 & 3399 & 2 & Water-neutral \\
\hline Vegetables & 0.75 & 24 & 411 & 6 & 80.52 & 543 & -18 & Water-friendly \\
\hline Fruits & 0.27 & 9 & 319 & 5 & 29.52 & 1159 & -4 & Water-friendly \\
\hline Livestock & 0.09 & 3 & 633 & 9 & 10.56 & 6376 & 6 & Water-intensive \\
\hline Coffee and tea & 0.01 & 0 & 82 & 1 & 1.25 & 6997 & 1 & Water-neutral \\
\hline
\end{tabular}




\subsection{Influence of Socio-Economic Status on Water and Food Nexus}

The total embedded waters in food consumption for the HMDA region were analyzed for twelve different ECs, i.e., EC1-12; high numbers corresponded to high consumption power. As one would expect, the per capita food consumption increased with increase in spending power (Figure S1); in particular, the per capita consumption values increased linearly until EC7, and then an exponential increase was observed for middle and upper economic classes beyond EC7 (Table 2). Meanwhile, the population increased from the lower to middle economic classes (EC1-6), it appeared to be random in the middle economic classes (EC7-9), and that was followed by decreases in the upper economic classes (EC10-12); a relatively low population was observed for upper economic classes (Table 2). Thus, the twelve economic classes were found to be unique and implicitly indicated the corresponding population's spending power and lifestyle including food that could be afforded and consumed.

The embedded water in each economic class across all the food groups increased for the first six economic classes and was followed by no systematic pattern in the middle economic classes (EC6-10) with decreased amounts in the upper economic classes (EC11 and EC12) (Table 2) - a similar pattern was observed for population distribution for all ECs. The middle economic classes had a high total embedded waters, i.e., EC10 with the highest embedded water contents (1031 MCM/year) followed by EC8 and EC9. As one would expect, the lowest embedded water contents were observed in the lower economic classes and could be attributed to small population numbers and a small total consumed quantity. However, it is important to note relatively low embedded waters were also observed in the upper economic classes (EC11 and EC12). EC11 and EC12 had the highest spending power, but their relatively decreased population numbers produced relatively low embedded water levels (Table 2). In contrast, high embedded waters were observed in the middle economic classes regardless of their relatively low per capita consumption compared to upper economic classes. This was because of the large population in middle economic classes. Unlike the total embedded water, the per capita embedded waters increased with increased spending power, thus suggesting a larger consumption water footprint for a person with more spending power (Table 2).

Table 2. Details of spending capacity, population, per capita embedded water, and total embedded water for all twelve economic classes.

\begin{tabular}{ccccc}
\hline Economic Class & $\begin{array}{c}\text { Spending Capacity } \\
\text { (Rupees/Capita/Month) }\end{array}$ & Population & $\begin{array}{c}\text { Per capita Embedded Water Content } \\
\text { (Cubic Meters/Capita/Year) }\end{array}$ & $\begin{array}{c}\text { Total Embedded Water } \\
\text { (MCM/year) }\end{array}$ \\
\hline 1 & $<725$ & 131806 & 493 & 65 \\
\hline 2 & 860 & 244783 & 515 & 341 \\
\hline 3 & 1090 & 593128 & 574 & 582 \\
\hline 4 & 1295 & 941472 & 619 & 650 \\
\hline 5 & 1510 & 997961 & 652 & 727 \\
\hline 6 & 1760 & 1063864 & 683 & 705 \\
\hline 7 & 2070 & 988546 & 713 & 961 \\
\hline 8 & 2460 & 1289817 & 745 & 795 \\
\hline 9 & 3070 & 1054449 & 830 & 1032 \\
\hline 10 & 4280 & 1242744 & 917 & 440 \\
\hline 11 & 6015 & 480151 & 955 & 369 \\
\hline
\end{tabular}

A plot of the total embedded water of food groups and economic classes suggested four-clusters of food groups and three clusters of economic classes (Figure 4). The food 
groups were as follows: cereals, milk products, livestock, pulses, vegetables, oils and fats, and fruits, as well as a cluster of sugars, coffee, and tea. Similarly, the three economic classes were as follows: EC4-10; these together corresponded to $~ 80 \%$ of the embedded water content in the HMDA region, including upper economic classes EC11 and EC12 $(\sim 12 \%)$ and lower economic classes EC1-3 ( 8\%). Note that population distribution across economic classes exhibited a similar pattern except that upper and lower economic classes corresponded to similar percentage equivalents of $9 \%$ and $8 \%$, respectively. As mentioned in the previous section, cereals, a water-intensive food group, held a large volume of embedded water for the HMDA region, which was seen in all economic classes (Figure 4a). The volume of embedded water of the milk products, which held the second most embedded water content of the HMDA region, greatly differed compared to cereals, except for in the upper economic classes. The decreased volumes of embedded waters and approximately similar volumes for the upper economic classes (EC11 and EC12) for both cereals and milk products indicated changes in food habits compared to the other economic classes (Figure 4a).
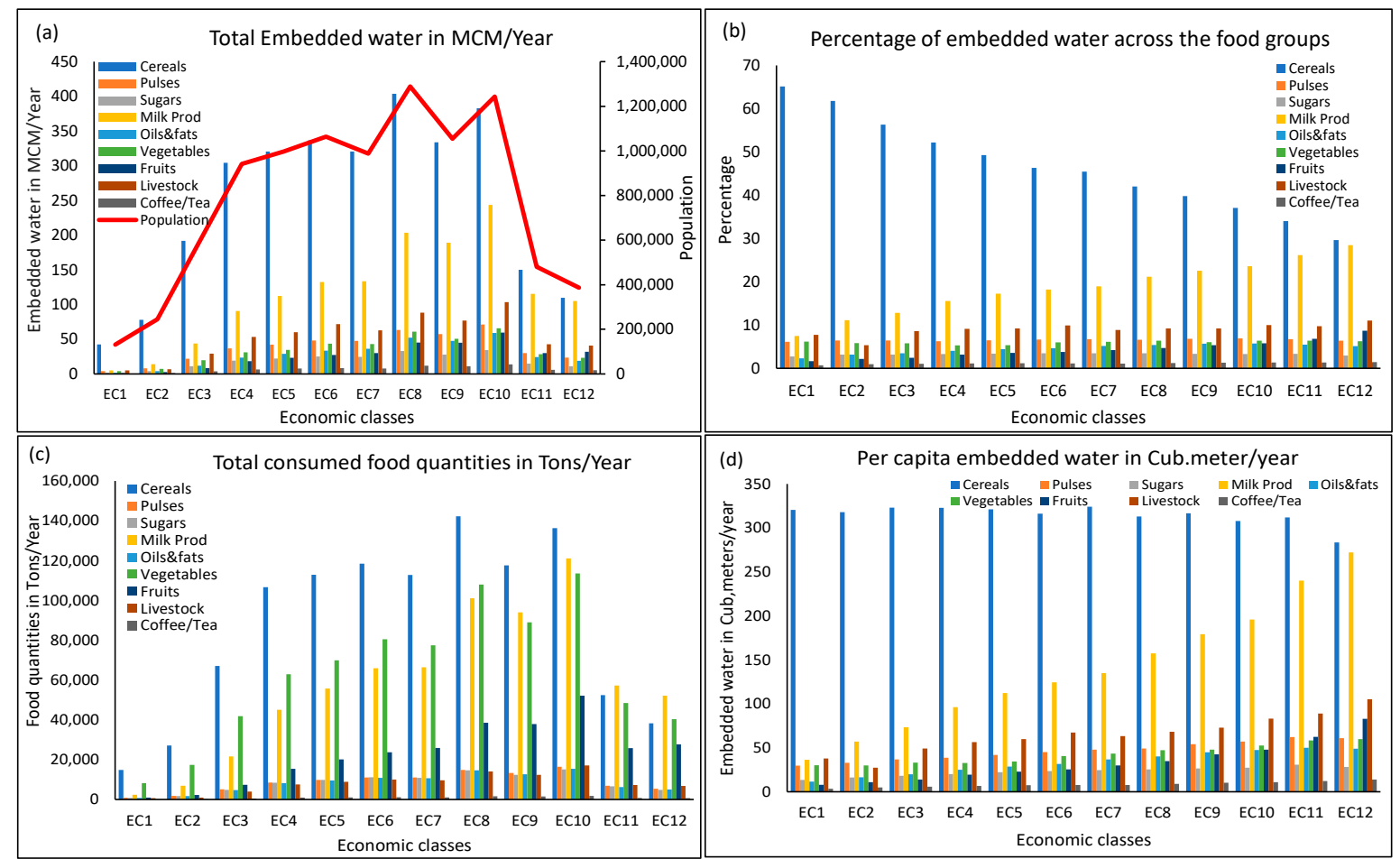

Figure 4. Total embedded water for each food group and each economic class, the plots also have population information on the right side of $y$-axis (a); similar to (a), but for the percentage equivalent of embedded water (b); similar to (a), but for total consumed food quantities (c); and similar to (a), but for per capita embedded water (d).

The food group of fruits held the second-lowest embedded water content in EC1-4. With the increase in spending power, the fruit group held more and more embedded water, and it was the food group with the fourth-highest embedded water content for EC11 and EC12. Fruits corresponded to a relatively low production WF, but their large total consumed quantities (ranked fourth) resulted in steep increases in its percentage equivalents; the high per capita consumed water footprint explained its increased total embedded water content for EC11 and EC12 (Figure 4b).

Livestock dominated as the third highest food group in terms of the HMDA region's water consumption footprint but corresponded to low food consumed quantities (ranked approximately sixth) in all economic classes, thus making it a water-intensive food group (Figure 4a,c); a similar observation was made in earlier sections. However, note that the percent equivalent was slightly on the rise in the low and high economic classes (Figure $4 \mathrm{~b}$ ). 
Pulses, another water-intensive food group, held approximately similar proportions of embedded water across all economic classes (Figure $4 \mathrm{~b}$ ) but consumed less than livestock (Figure 4c). Consequently, the pulses group had a relatively low embedded water content compared to livestock (Figure 4a). In contrast, vegetables, as observed in Figure 4a, comprised the second most-consumed food group for all economic classes but held a low embedded water content because it had the lowest production WF. Hence, it was designated as a water-friendly group. Its percent equivalent, i.e., the proportion of the total food in an economic class, was approximately same across all economic classes $(\sim 6 \%)$ and was smaller than percent equivalent of livestock $(\sim 10 \%)$. While sugars held more embedded water than fruits in the lower economic classes, it is important to note that the quantities of both embedded waters and total consumed quantities were relatively small (Figure $4 \mathrm{a}, \mathrm{c})$. The percent equivalents of the sugars group and the coffee and tea group, i.e., 4 and $1.5 \%$, respectively, were approximately constant across all economic classes. Being water-neutral groups, their roles in the embedded waters of the HMDA regions are small. A low embedded water amount consequently led to smaller proportions of the percent equivalent of total embedded waters of the HMDA region of lower economic classes, thus indicating its smaller role in consumption WF, e.g., the cereals percent equivalent was very high for the lower economic classes but its total embedded water was small. In general, total embedded waters and total consumed quantities followed the pattern of the population distribution of each economic class, and the combination of embedded waters and total consumed quantities highlighted the dietary habits of the economic classes (Figure $4 a, c)$.

Total embedded water per capita suggests, in general, the volume of water consumption associated with a food product by an economic class. Being independent of population, these values reflect the potential water consumption of each economic class, and the values associated with each food group were found to vary across economic classes (Figure $4 \mathrm{~d}$ ). Except for cereals, the per capita water consumption of all food groups increased with the spending power of the economic class; approximately similar values for cereals for all economic classes suggested no role of an increased population in an economic class. Meanwhile, in the case of the milk products, the values exhibited a steep rate of changes and high values in middle and upper economic classes. This indicated milk products potential roles in the region's consumption WF. Th other food products because of its small values, regardless of its moderate- (livestock), mild- (pulses, vegetables, oil and fats, and fruits), and flat-rate (sugars and coffee/tea) changes across economic classes, indicated its lesser role concerning population changes. Note that multiplication of per capita embedded water with population did not yield the total embedded water as the total embedded waters calculated from individual food products. In this regard, the consumption WF by each of the food products was analyzed (Table S1).

The three food products entitled rice-other sources, wheat/atta-other sources, and milk-liquid corresponded to approximately $55 \%$ of the total embedded water in an economic class (Figure S2). Meanwhile, two other products, i.e., rice-public distribution system and wheat/atta-public distribution system accounted for approximately 10-20\% for the lower economic classes, and the percentage equivalent decreased for the middle and upper economic classes. The economic classes with higher spending power are excluded from benefitting the supply of food products from the public distribution system. Therefore, they corresponded to smaller percentage equivalents of total embedded water. Nevertheless, the combination of rice, wheat/atta, and milk-liquid in each economic class held approximately $63-78 \%$ of total embedded water with low- and high-percentage equivalents in upper and lower economic classes, respectively. Despite most of the proportion was from the water-intensive food group, being staple foods the opportunity to decrease the consumption WF is minimal. Only a few products in some economic classes had a percentage equivalent between 2 and 6; otherwise, many individual food products had smaller proportions and did not assist in decreasing the total embedded water of the region 


\subsection{Potential Policy Interventions with Nexus Approach for Water Conservation}

The total amount of consumption of water footprint for the HMDA region was found to be $6836 \mathrm{MCM}$ per year, and of which green, blue, and grey water corresponded to 67 , 23 , and $10 \%$, respectively (Figure $5 a$, last column). The values suggested that much of the water that is being consumed in the HMDA region is precipitation-driven, followed by surface and groundwater resources. The grey WF percentage equivalent, $10 \%$, implied non-negligible pollutant loads as a result of food consumption. A similar inference could be derived from the values of percentage equivalent of the individual food groups, i.e., green WF percentage equivalent followed by the blue WF and grey WF percentage equivalents (Figure 5a). The green WF percentage equivalent ranged from approximately 50 to 95 , and the food group of oils and fats group had the highest proportion, thus indicates its dependency on precipitation-driven water sources (Figure 5a). The sugars and cereals food groups corresponded to the first two highest percentage equivalent blue water sources, i.e., 45 and $37 \%$, respectively (Figure $5 a$ ). Among all food groups, pulses corresponded to the highest greywater percentage equivalent, $\sim 23 \%$. However, note that the mentioned food groups, except for cereals, held small amounts of the embedded waters of the HMDA region regardless of their high percentage equivalents (see Table 1).
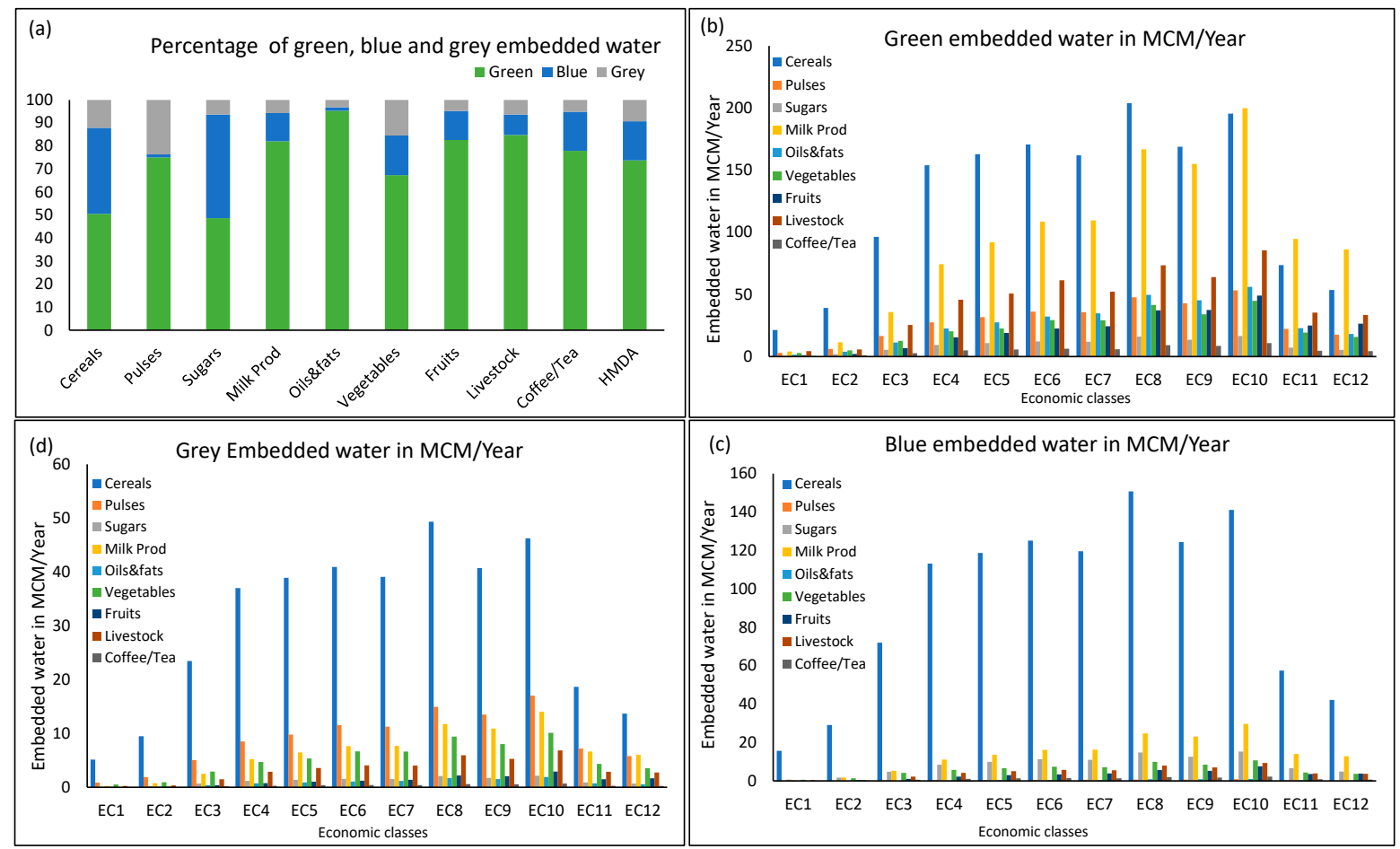

Figure 5. Percentage of green, blue and grey embedded water for each food group and the HMDA region (a), as well as the amount of green (b), blue (c), and grey (d) embedded water contents for each food group and each economic class.

The patterns of the consumption green, blue, and grey WFs concerning the economic classes were not much different from total consumption WF, which was the weighted sum of all three individual water footprints (Figure $5 b-d$ vs. Figure $4 a$ ). Cereals and milk products corresponded to high consumption WF values, and their corresponding green, blue, and grey embedded waters were also relatively high. A high consumption $\mathrm{WF}$, as discussed, is mainly driven by large quantities of total consumed food and high values of water production footprint. Relatively, sugars and pulses corresponded to small consumed food quantities, though they nevertheless corresponded to third and second highest embedded waters for blue and grey waters, respectively (Figure $5 c, d$ ). The volume of blue and grey embedded water in the city's consumption for many products was small, but cereals and milk product's blue embedded water and cereal's grey embedded water 
values were higher than a few products' green embedded water. The values for the food products entitled milk-liquid, rice-other sources, wheat/atta-other sources, chicken, and oils and fats accounted for a significant amount of individual waters; note that some of their percentage equivalents were small, and corresponding food groups were ranked as the highest contributors of the city's consumption WF (Table S1). In this regard, the blue and grey embedded water may have a potential role in the HMDA region's consumption water footprint.

In general, the values suggested the importance of rainfall (source for green water) followed by the surface and groundwater resources (source for blue water) of the HMDA region's consumption WF. Grey water is the amount of water that negates the influence of pollutants, so it also dependent on water resources. The fact that consumption WF is dependent on natural resources that are limited in quantity and, importantly, have variability highlights the importance of setting up guidelines and policies to make urban regions self-reliant. Curtailing exports during the recent pandemic hit the headlines in countries giving priority to food, water, and energy security for their self-sufficiency [48,49], but similar situation could happen under adverse climatic conditions. Consequently, foodimporting regions have faced severe problems for food and water needs. Thus, policy drafting should account for the above-mentioned and future increases in consumption WF.

The entire process involves great efforts including the consideration of the uncertainties associated with the estimates and the overcoming of the limitations of the current study, as discussed below. Uncertainties in consumption WF estimates resulted from multiple sources including errors in the data that were obtained based on surveys. The data that were used in the current study were derived over one year and thus did not necessarily reflect the dynamics in recent years and future projections of urban development, e.g., the conversion of peri-urban agriculture and fertile croplands elsewhere to urban lands $[4,67,68]$. Additionally, note that the production WF varies regionally, but the regional water footprint for peri-urban of the HMDA region was not available and, hence, not considered. Similarly, the water footprint is not available for transportation or approximated for consumption WF calculations. These issues highlight the importance of the collection of additional data including the data of more food products from other than basic food groups. The future estimates should consider changes in dietary habits across different economic classes. Changes in dietary habits are inevitable for the migration of more and more people to the HMDA region for better livelihoods, the promotion of large-scale initiatives for alternate cereal products (e.g., maize, finger millet, and sorghum) that use less blue water resources $[69,70]$, and changes in population distribution across economic classes because of the projected economic growth in the region [71].

Apart from all the above factors including proposed economic growth, climate will have a significant role in drafting policy. There is literature suggesting changes in rainfall patterns, e.g., an increased number of rainfall events with a high intensity and decreased duration is on the rise $[72,73]$ and its effects will not necessarily be limited to urban, periurban, and rural regions. The adverse effect of climate change on both green or blue water resources may lead to additional stress for water resources and, in combination with the unsustainable consumption of water for irrigation [74], further increase the effects of limited water resources. In particular, urban heat islands effects need to be studied [75,76]. The study region received a significant amount of rainfall that led to floods this year [77], but decreased ground and reservoir water levels, as well as the possibility of not meeting the region's demands, were highly discussed topics a few years ago [78]. Multiple reservoirs of moderate-to-large sizes (stores of $\sim 80 \mathrm{MCM}$ of water per month) [79] and water distribution systems may dampen the climate change effects for a short period, but available water resources in the context of climate change's impacts on irrigation in the peri-urban region need to be analyzed and integrated into water footprint-based policies. 


\section{Conclusions}

This study calculated the total amount of consumed food quantities and embedded water for different food product groups and economic classes. Embedded waters were used to analyze the water and food nexus for food groups among the economic classes in the HMDA region. Thus, the consumption water footprint of various food products associated with the socio-economic status of the region was interpreted. The food products were grouped into nine food groups, namely cereals, fruits, livestock, coffee and tea, milk products, oils and fats, pulses, sugars, and vegetables, and then the food groups categorized into water-intensive, water-neutral, and water-friendly groups based on their percent equivalent of consumed food and embedded waters. Cereals, vegetables, and milk products were the highly consumed food products, and, based on the associated embedded waters, these were categorized as water-intensive, water-friendly, and water-neutral food groups, respectively. While livestock was consumed relatively less in all economic classes, it has been treated as water-intensive food group because it holds significant amounts of embedded waters. The total embedded waters increased for the first six economic classes, followed by no systematic pattern in the middle economic classes, and finally ending with decreased amounts for the upper economic classes. The middle economic classes together corresponded to $\sim 80 \%$ of total embedded water content in the HMDA region, followed by the upper economic classes EC11 and EC12 ( 12\%), and then the lower economic classes EC1-3 ( 8\%). Decreased volumes of embedded waters in combination with approximately similar volumes for both cereals and milk products indicated changes in food habits for the upper economic class as compared to the other economic classes, e.g., fruits ranked as the fourth in terms of embedded waters for EC11 and EC12. Largely, embedded waters and total consumed quantities followed the pattern of the population distribution of each economic class. Unlike total embedded water, the per capita embedded waters, except for cereals, increased with an increase in spending power that suggested a larger consumption water footprint for a person with more spending power. However, for cereals, all economic classes exhibited a similar potential consumption water footprint. While most of the proportion of total embedded water comes from a few groups, of which cereals are waterintensive, the fact is that these staple foods did not allow for the opportunity to decrease the consumption WF. That total consumption WF of the region was dominated by green WF, followed by blue and grey WF, suggests the role of precipitation, surface, and ground water resources. In this regard and as the region is expected to grow, a detailed study to make the region self-reliant is suggested.

Supplementary Materials: The following are available online at https:/ / www.mdpi.com/2073-444 1/13/5/637/s1. Figure S1: Per capita food consumption in tons/capita/year for all nine food groups and for twelve economic classes; Figure S2: Percentage equivalent of total embedded water of Milk liquid, wheat, rice from other sources (a); percentage equivalent of total embedded water for rice and wheat from PDS (b); Table S1: Green, blue and grey water for individual food products over the HMDA region, MCM-Million Cubic Meters.

Author Contributions: Conceptualization, K.R.D.; methodology, K.R.D.; software, K.R.D.; formal analysis, K.R.D. and S.K.R. and C.D.; investigation, K.R.D., S.K.R.; resources, S.K.R.; data curation, K.R.D.; writing —original draft preparation, K.R.D.; writing—review and editing, K.R.D., S.K.R., and C.D.; visualization, K.R.D.; supervision, S.K.R.; project administration, S.K.R. All authors have read and agreed to the published version of the manuscript.

Funding: This research was funded by the Ministry of Human Resources Development (MHRD) of India at the Indian Institute of Technology Hyderabad.

Institutional Review Board Statement: Not applicable.

Informed Consent Statement: Not applicable.

Data Availability Statement: All the data mentioned in the Section 3.1 is available online. 
Acknowledgments: The authors would like to acknowledge support from the Frontier Areas of Science and Technology-Center of Excellence (FAST-CoE) in Sustainable Development at Indian Institute of Technology Hyderabad and Ministry of Human Resources Development, India, for supporting and funding this project. The authors would like to acknowledge reviewers and Anjal Prakash, ISB Hyderabad, for their insightful comments.

Conflicts of Interest: Authors declare that they do not have any conflict of interest.

\section{References}

1. De Zeeuw, H.; Dubbeling, M. The Future of Cities-Opportunities, Challenges and the Way Forward; European Commission, Joint Research Center: Luxembourg, 2019.

2. Gumma, M.K.; Mohammad, I.; Nedumaran, S.; Whitbread, A.; Lagerkvist, C.J. Urban sprawl and adverse impacts on agricultural land: A case study on Hyderabad, India. Remote Sens. 2017, 9, 1136. [CrossRef]

3. Maheshwari, B.; Purohit, R.; Malano, H.; Singh, V.P.; Amerasinghe, P. Water Science and Technology Library Challenges and Opportunities for Peri-Urban Futures; Springer: Dordrecht, Germany, 2014; ISBN 9789401788779.

4. Heard, B.R.; Miller, S.A.; Liang, S.; Xu, M. Emerging challenges and opportunities for the food-energy-water nexus in urban systems. Curr. Opin. Chem. Eng. 2017, 17, 48-53. [CrossRef]

5. Keskinen, M.; Guillaume, J.H.A.; Kattelus, M.; Porkka, M.; Räsänen, T.A.; Varis, O. The water-energy-food nexus and the transboundary context: Insights from large Asian rivers. Water (Switzerland) 2016, 8, 193. [CrossRef]

6. Covarrubias, M.; Boas, I. The making of a sustainable food city in Barcelona: Insights from the water, energy, and food urban nexus. J. Integr. Environ. Sci. 2020, 17, 1-19. [CrossRef]

7. Covarrubias, M.; Spaargaren, G.; Boas, I. Network governance and the Urban Nexus of water, energy, and food: Lessons from Amsterdam. Energy. Sustain. Soc. 2019, 9, 1-11. [CrossRef]

8. Covarrubias, M. The nexus between water, energy and food in cities: Towards conceptualizing socio-material interconnections. Sustain. Sci. 2019, 14, 277-287. [CrossRef]

9. Cornelsen, L.; Green, R.; Turner, R.; Dangour, A.D.; Shankar, B.; Mazzocchi, M.; Smith, R.D. What happens to patterns of food consumption when food prices change? evidence from a systamatic review and meta-analysis of food price elasticities globally. Health Econ. 2013, 19, 1300-1317. [CrossRef]

10. Mahjabin, T.; Garcia, S.; Grady, C.; Mejia, A. Large cities get more for less: Water footprint efficiency across the US. PLoS ONE 2018, 13, e0202301. [CrossRef]

11. Popkin, B.M.; Corvalan, C.; Grummer-Strawn, L.M. Dynamics of the double burden of malnutrition and the changing nutrition reality. Lancet 2020, 395, 65-74. [CrossRef]

12. Jalava, M.; Kummu, M.; Porkka, M.; Siebert, S.; Varis, O. Diet change-A solution to reduce water use? Environ. Res. Lett. 2014, 9. [CrossRef]

13. Kinnunen, P.; Guillaume, J.H.A.; Taka, M.; D’Odorico, P.; Siebert, S.; Puma, M.J.; Jalava, M.; Kummu, M. Local food crop production can fulfil demand for less than one-third of the population. Nat. Food 2020, 1, 229-237. [CrossRef]

14. Hoff, H. Understanding the Nexus Background Paper for the Bonn2011 Conference: The Water, Energy and Food Security Nexus; Stockholm Environment Institute: Stockholm, Swedan, 2011.

15. Kaddoura, S.; El Khatib, S. Review of water-energy-food Nexus tools to improve the Nexus modelling approach for integrated policy making. Environ. Sci. Policy 2017, 77, 114-121. [CrossRef]

16. Dhabi, A.; Emirates, U.A.; Rizk, Z.; Emirates, U.A. Smart Cities in the Gulf. Smart Cities Gulf 2018, 85-106. [CrossRef]

17. Daher, B.; Lee, S.H.; Kaushik, V.; Blake, J.; Askariyeh, M.H.; Shafiezadeh, H.; Zamaripa, S.; Mohtar, R.H. Towards bridging the water gap in Texas: A water-energy-food nexus approach. Sci. Total Environ. 2019, 647, 449-463. [CrossRef] [PubMed]

18. Lee, S.H.; Mohtar, R.H.; Yoo, S.H. Assessment of food trade impacts on water, food, and land security in the MENA region. Hydrol. Earth Syst. Sci. 2019, 23, 557-572. [CrossRef]

19. Bahn, R.; El Labban, S.; Hwalla, N. Impacts of shifting to healthier food consumption patterns on environmental sustainability in MENA countries. Sustain. Sci. 2018, 3, 1131-1146. [CrossRef]

20. Gupta, E. The impact of solar water pumps on energy-water-food nexus: Evidence from Rajasthan, India. Energy Policy 2019, 129, 598-609. [CrossRef]

21. Siegfried, T.; Sobolowski, S.; Raj, P.; Fishman, R.; Vasquez, V.; Narula, K.; Lall, U.; Modi, V. Modeling irrigated area to increase water, energy, and food security in semiarid India. Weather Clim. Soc. 2010, 2, 255-270. [CrossRef]

22. Al-Zu'bi, M. Water-Energy-Food-Climate Change Nexus in The Arab Cities: The Case of Amman City, Jordan. Ph.D. Thesis, University of Calgary, Calgary, AB, Canada, 2017; p. 380. [CrossRef]

23. Da Costa Silva, G. Climate change and the water-energy nexus: An urban challenge. J. Water Clim. Chang. 2014, 5, 259-275. [CrossRef]

24. Lorah, H. The Water-Energy Nexus in Large Cities; Princeton university: Princeton, NJ, USA, 2017; pp. 1-75.

25. Daher, B.T.; Mohtar, R.H. Water-energy-food (WEF) Nexus Tool 2.0: Guiding integrative resource planning and decision-making. Water Int. 2015, 40, 748-771. [CrossRef]

26. McCallum, J.L.; Shanafield, M. Water Resources Research. Water Resour. Res. 2016, 52, 1-20. [CrossRef] 
27. Gondhalekar, D.; Ramsauer, T. Nexus City: Operationalizing the urban Water-Energy-Food Nexus for climate change adaptation in Munich, Germany. Urban Clim. 2017, 19, 28-40. [CrossRef]

28. Ramaswami, A.; Boyer, D.; Nagpure, A.S.; Fang, A.; Bogra, S.; Bakshi, B.; Cohen, E.; Rao-Ghorpade, A. An urban systems framework to assess the trans-boundary food-energy-water nexus: Implementation in Delhi, India. Environ. Res. Lett. 2017, 12, 025008. [CrossRef]

29. Boyer, D.; Sarkar, J.; Ramaswami, A. Diets, Food Miles, and Environmental Sustainability of Urban Food Systems: Analysis of Nine Indian Cities. Earth's Future 2019, 7, 911-922. [CrossRef]

30. Boyer, D. Comparing urban food system characteristics and actions in US and Indian cities from a multi-environmental impact perspective Toward a streamlined approach. J. Ind. Ecol. 2020, 24, 841-854. [CrossRef]

31. Blas, A.; Garrido, A.; Willaarts, B. Food consumption and waste in Spanish households: Water implications within and beyond national borders. Ecol. Indic. 2018, 89, 290-300. [CrossRef]

32. Harris, F.B.; Green, R.; Joy, E.; Haines, A.; Dangour, A. The Water Use of Diets in India. Ann. Glob. Health 2017, 83, 89. [CrossRef]

33. Harris, F.; Green, R.F.; Joy, E.J.M.; Kayatz, B.; Haines, A.; Dangour, A.D. The water use of Indian diets and socio-demographic factors related to dietary blue water footprint. Sci. Total Environ. 2017, 587-588, 128-136. [CrossRef]

34. Kang, J.; Lin, J.; Zhao, X.; Zhao, S.; Kou, L. Decomposition of the Urban Water Footprint of Food Consumption: A Case Study of Xiamen City. Sustainability 2017, 9, 135. [CrossRef]

35. Vanham, D.; Bidoglio, G. The water footprint of Milan. Water Sci. Technol. 2014, 69, 789-795. [CrossRef] [PubMed]

36. Vanham, D. The water footprint of Austria for different diets. Water Sci. Technol. 2013, 67, 824-830. [CrossRef] [PubMed]

37. Vanham, D.; Comero, S.; Gawlik, B.M.; Bidoglio, G. The water footprint of different diets within European sub-national geographical entities. Nat. Sustain. 2018, 1, 518-525. [CrossRef]

38. Vanham, D.; Gawlik, B.M.; Bidoglio, G. Cities as hotspots of indirect water consumption: The case study of Hong Kong. J. Hydrol. 2017. [CrossRef]

39. Borowski, P.F. Nexus between water, energy, food and climate change as challenges facing the modern global, European and Polish economy. AIMS Geosci. 2020, 6, 397-421. [CrossRef]

40. Url, O.; Monograph, P.V.; Middle, L.S.E.; Centre, E.; Series, P.; Centre, M.E. Characterising the Water-Energy-Food Nexus in Kuwait and the Gulf region. Lond. Sch. Econ. Middle East Cent. 2019, 28, 1-75.

41. Dobbs, R.; Smit, S.; Remes, J.; Manyika, J.; Roxburgh, C.; Restrepo, A. Urban world: Mapping the economic power of cities. World 2011, 46, 1-49.

42. Vanham, D.; Hoekstra, A.Y.; Wada, Y.; Bouraoui, F.; de Roo, A.; Mekonnen, M.M.; van de Bund, W.J.; Batelaan, O.; Pavelic, P.; Bastiaanssen, W.G.M.; et al. Physical water scarcity metrics for monitoring progress towards SDG target 6.4: An evaluation of indicator 6.4.2 "Level of water stress". Sci. Total Environ. 2018, 613-614, 218-232. [CrossRef]

43. Fialkiewicz, W.; Burszta-Adamiak, E.; Kolonko-Wiercik, A.; Manzardo, A.; Loss, A.; Mikovits, C.; Scipioni, A. Simplified direct water footprint model to support urban water management. Water (Switzerland) 2018, 10, 630. [CrossRef]

44. Scipioni, A.; Manzardo, A.; Loss, A.; Rosa, V.; Kolonko, A.; Malinowski, P.; Leonhardt, G.; Rauch, W.; Haida, C.; Schneider, K.; et al. Water footprint in strategic water management at the urban level: The urban wftp european project. Water Footpr. Eur. 2014, 1, 143-147.

45. Manzardo, A.; Loss, A.; Fialkiewicz, W.; Rauch, W.; Scipioni, A. Methodological proposal to assess the water footprint accounting of direct water use at an urban level: A case study of the Municipality of Vicenza. Ecol. Indic. 2016, 69, 165-175. [CrossRef]

46. Koteswara Rao, D.; Chandrasekharam, D. Quantifying the water footprint of an urban agglomeration in developing economy. Sustain. Cities Soc. 2019, 50, 101686. [CrossRef]

47. Baer-Nawrocka, A.; Sadowski, A. Food security and food self-sufficiency around the world: A typology of countries. PLoS ONE 2019, 14, e0213448. [CrossRef]

48. Sohrabi, C.; Alsafi, Z.; O’Neill, N.; Khan, M.; Kerwan, A.; Al-Jabir, A.; Iosifidis, C.; Agha, R. World Health Organization declares global emergency: A review of the 2019 novel coronavirus (COVID-19). Int. J. Surg. 2020, 76, 71-76. [CrossRef]

49. Zurayk, R. Pandemic and Food Security: A View from the Global South. J. Agric. Food Syst. Community Dev. 2020, 9, 1-5. [CrossRef]

50. Kundzewicz, Z.W.; Kanae, S.; Seneviratne, S.I.; Handmer, J.; Nicholls, N.; Peduzzi, P.; Mechler, R.; Bouwer, L.M.; Arnell, N.; Mach, K.; et al. Le risque d'inondation et les perspectives de changement climatique mondial et régional. Hydrol. Sci. J. 2014, 59, 1-28. [CrossRef]

51. Perkins-Kirkpatrick, S.E.; Lewis, S.C. Increasing trends in regional heatwaves. Nat. Commun. 2020, 11, 1-8. [CrossRef] [PubMed]

52. Green, R.F.; Joy, E.J.M.; Harris, F.; Agrawal, S.; Aleksandrowicz, L.; Hillier, J.; Macdiarmid, J.I.; Milner, J.; Vetter, S.H.; Smith, P.; et al. Greenhouse gas emissions and water footprints of typical dietary patterns in India. Sci. Total Environ. 2018, 643, 1411-1418. [CrossRef]

53. Suparana Katyaini, A.B. Water Resources Research. Water Resour. Res. 2017, 1-18. [CrossRef]

54. Fickling, D. How India's Water Ends Up Everywhere But India. Available online: https://www.bloombergquint.com/gadfly/ india-is-the-world-s-biggest-exporter-of-water-despite-shortages (accessed on 25 June 2020).

55. SreeVidhya, K.S.; Elango, L. Temporal variation in export and import of virtual water through popular crop and livestock products by India. Groundw. Sustain. Dev. 2019, 8, 468-473. [CrossRef] 
56. Anand, A.; Sreevatsan, A.; Taraporevala, P. An overview of the smart cities mission in India. SCM Policy Brief Cent. Policy Res. 2018. Available online: https://smartnet.niua.org/sites/default/files/resources/scm_policy_brief_28th_aug.pdf (accessed on 25 June 2020).

57. Marttunen, M.; Mustajoki, J.; Sojamo, S.; Ahopelto, L.; Keskinen, M. A framework for assessing water security and the waterenergy-food nexus-the case of Finland. Sustainability 2019, 11, 2900. [CrossRef]

58. Le Blanc, D. Towards Integration at Last? The Sustainable Development Goals as a Network of Targets. Sustain. Dev. 2015, 23, 176-187. [CrossRef]

59. Prakash, A. The periurban water security problem: A case study of Hyderabad in Southern India. Water Policy 2014, 16, 454-469. [CrossRef]

60. HMDA. Report on Data Compilation and Statistical Analysis Volume I: Household Interview Survey Analysis; Hyderabad Metro Development Authority: Hyderabad, India, 2012.

61. Hyderabad Population 2021 (Demographics, Maps, Graphs). Available online: https://worldpopulationreview.com/worldcities/hyderabad-population (accessed on 20 February 2021).

62. Van Rooijen, D.J.; Biggs, T.W.; Smout, I.; Drechsel, P. Urban growth, wastewater production and use in irrigated agriculture: A comparative study of Accra, Addis Ababa and Hyderabad. Irrig. Drain. Syst. 2010, 24, 53-64. [CrossRef]

63. NSSO and MSPI. Household Consumption of Various Goods and Services in India; Ministry of Statistics and Program Implementation: Delhi, India, 2012; Volume 558.

64. NIN. Nation Institute of Nutrition Dietary Guidelines; Hyderabad, Indian Council of Medical research: Hyderabad, India, 2011; ISBN 1864965746.

65. Mekonnen, M.M.; Hoekstra, A.Y. The green, blue and grey water footprint of farm animals and animal products. Volume 2: Appendices. Water Res. 2010, 2, 122.

66. Mekonnen, M.M.; Hoekstra, A.Y. The green, blue and grey water footprint of crops and derived crop products. Hydrol. Earth Syst. Sci. 2011, 15, 1577-1600. [CrossRef]

67. Chen, G.; Li, X.; Liu, X.; Chen, Y.; Liang, X.; Leng, J.; Xu, X.; Liao, W.; Qiu, Y.; Wu, Q.; et al. Global projections of future urban land expansion under shared socioeconomic pathways. Nat. Commun. 2020, 11, 1-12. [CrossRef]

68. Gerten, D.; Heck, V.; Jägermeyr, J.; Bodirsky, B.L.; Fetzer, I.; Jalava, M.; Kummu, M.; Lucht, W.; Rockström, J.; Schaphoff, S.; et al. Feeding ten billion people is possible within four terrestrial planetary boundaries. Nat. Sustain. 2020, 1-9. [CrossRef]

69. Davis, K.F.; Chhatre, A.; Rao, N.D.; Singh, D.; Ghosh-Jerath, S.; Mridul, A.; Poblete-Cazenave, M.; Pradhan, N.; DeFries, R. Assessing the sustainability of post-Green Revolution cereals in India. Proc. Natl. Acad. Sci. USA 2019, 116, 25034-25041. [CrossRef] [PubMed]

70. Davis, K.F.; Chiarelli, D.D.; Rulli, M.C.; Chhatre, A.; Richter, B.; Singh, D.; DeFries, R. Alternative cereals can improve water use and nutrient supply in India. Sci. Adv. 2018, 4, eaao1108. [CrossRef] [PubMed]

71. Gurram, M.K.; Kinthada, N.R. Influence of Demographic and Socio-Economic Variations in Shaping Urban Structure-A Ward Level Study on Hyderabad, Telangana using Remote Sensing and GIS Techniques. Int. J. Eng. Sci. Math. 2018, 7, 55-63.

72. Agilan, V.; Umamahesh, N.V. Detection and attribution of non-stationarity in intensity and frequency of daily and 4-h extreme rainfall of Hyderabad, India. J. Hydrol. 2015, 530, 677-697. [CrossRef]

73. Vemula, S.; Srinivasa Raju, K.; Sai Veena, S. Modelling impact of future climate and land use land cover on flood vulnerability for policy support-Hyderabad, India. Water Policy 2020, 22, 733-747. [CrossRef]

74. Rosa, L.; Chiarelli, D.D.; Tu, C.; Rulli, M.C.; D'odorico, P. Global unsustainable virtual water flows in agricultural trade. Environ. Res. Lett. 2019, 14. [CrossRef]

75. Bala, R.; Prasad, R.; Yadav, V.P.; Sharma, J. Spatial variation of urban heat island intensity in urban cities using modis satellite data. Int. Arch. Photogramm. Remote Sens. Spat. Inf. Sci. ISPRS Arch. 2019, 42, 147-151. [CrossRef]

76. Sultana, S.; Satyanarayana, A.N.V. Urban heat island intensity during winter over metropolitan cities of India using remotesensing techniques: Impact of urbanization. Int. J. Remote Sens. 2018, 39, 6692-6730. [CrossRef]

77. Dimpiri So, Just Why Did Hyderabad Flood? Available online: https://www.downtoearth.org.in/blog/water/so-just-why-didhyderabad-flood--73875 (accessed on 22 December 2020).

78. Varma, R. Water Scarcity May Cause Upto 6\% Loss in GDP: World Bank. Available online: https: / /www.downtoearth.org.in/ news/water/water-scarcity-may-cause-upto-6-loss-in-gdp-world-bank-53816 (accessed on 22 December 2020).

79. Van Rooijen, D.J.; Turral, H.; Biggs, T.W. Sponge city: Water balance of mega-city water use and wastewater use in Hyderabad, India. Irrig. Drain. 2005, 54, 81-91. [CrossRef] 